\title{
Diversity patterns of ground-beetles (Coleoptera: Carabidae) along a gradient of land-use disturbance
}

\author{
Pedro Martins da Silva ${ }^{\mathrm{a}, \mathrm{c}, *}$, Carlos A.S. Aguiar ${ }^{\mathrm{a}}$, Jari Niemelä ${ }^{\mathrm{b}}$, \\ José Paulo Sousa $^{c}$, Artur R.M. Serrano ${ }^{\mathrm{a}}$ \\ ${ }^{a}$ Centro de Biologia Ambiental, Departamento de Biologia Animal, Faculdade de Ciências da Universidade de Lisboa, \\ R. Ernesto de Vasconcelos, Ed. C2-2 ${ }^{\circ}$ Piso, Campo Grande, 1749-016 Lisboa, Portugal \\ ${ }^{\mathrm{b}}$ Department of Biological and Environmental Sciences, University of Helsinki, P.O. Box 65, FIN-00014 Helsinki, Finland \\ c IMAR-Coimbra Interdisciplinary Centre, Department of Zoology, University of Coimbra, Largo Marquês de Pombal, 3004-517 Coimbra, Portugal
}

Received 9 May 2007; received in revised form 18 October 2007; accepted 24 October 2007

Available online 4 December 2007

\begin{abstract}
Ground-beetles were used to monitor biodiversity along a gradient of land-use disturbance, from old-growth cork-oak woodland to a monoculture, in a typical Mediterranean landscape. The work also included an exotic forest in the second year. During this study, a total of 11294 individuals of carabids from 101 different species were sampled (2001: $N=4776, S=80 ; 2002: N=6518, S=77)$. Agriculture unit recorded the highest abundance and richness levels, while the exotic forest recorded the lowest values. Moreover, higher diversity levels were observed in units dominated by open areas, particularly pastures. Nevertheless, mosaic units with major cork-oak cover revealed a higher number of species that are more sensitive to human disturbance, i.e., woodland specialists.
\end{abstract}

(C) 2007 Elsevier B.V. All rights reserved.

Keywords: Ground-beetles; Carabidae; Ecological indicator; Land-use disturbance; Cork-oak woodlands

\section{Introduction}

In theory, heterogeneous landscapes enclose higher species diversity levels than homogenous areas, since structurally complex habitats provide more niches and ways of resource exploitation (e.g., Sheil and Burslem, 2003; Tews et al., 2004). Habitat heterogeneity is especially high in typical Mediterranean landscapes, where a mix of silviculture (mainly Quercus suber) and traditional grazing practices provide a dynamic mosaic pattern of closed and open habitats, which enhances diversity through species turnover (Verdú et al., 2000; Taboada et al., 2006). In this context, the pan-European project "Biodiversity Assessment Tools"

\footnotetext{
* Corresponding author at: Centro de Biologia Ambiental, Departamento de Biologia Animal, Faculdade de Ciências da Universidade de Lisboa, R. Ernesto de Vasconcelos, Ed. C2-2 ${ }^{\circ}$ Piso, Campo Grande, 1749-016 Lisboa, Portugal. Tel.: +351 217500000x22143; fax: +351 217500028 .

E-mail address: pgpmartins@yahoo.co.uk (P.M. da Silva).
}

(BIOASSESS: http://www.nbu.ac.uk/bioassess/) aimed to develop a set of ecological indicators according to a landuse disturbance gradient, with significant increase of open landscapes (e.g., pastures and arable crops) in comparison to an old-growth woodland (Sousa et al., 2006). One of the taxa studied in the BIOASSESS project was carabid beetles. This group was selected as an ecological indicator due to several reasons, above all their great abundance and species richness in agroecosystems, as well as their wide distribution and sensitiveness to land-use change (e.g., Ribera et al., 2001; Rainio and Niemelä, 2003). Amongst the carabid species, habitat specialists (e.g., woodland stenotopic species) are particularly relevant as monitoring tools for conservation biology (Niemelä and Baur, 1998; Larsen et al., 2003; Warnaffe et al., 2004; Sroka and Finch, 2006). In this study we used ground-beetles as monitoring tools along a gradient of land-use disturbance (declining forest cover) in a typical Mediterranean landscape. Our goal was to test 'intermediate disturbance hypothesis (IDH)' specific prediction, i.e., species 
diversity would be higher at intermediate levels of disturbance, where the greatest landscape heterogeneity occurs (mix-use of silviculture and extensive grazing). We also aimed to test the response to the disturbance gradient taking into account different 'habitat preference groups' of ground-beetles, focusing on woodland specialist species considering their sensitiveness to disturbance and thereby their relevance to biodiversity conservation.

\section{Materials and methods}

The field work was conducted in a Mediterranean landscape of cork-oak areas (Q. suber) under different types of management, during 2 years (2001 and 2002). The sampling sites were located in the consolidated alluvial plain of the Tagus river (left bank), $20 \mathrm{~km}$ east of Lisbon, Portugal (ca. $42^{\circ} 50^{\prime} \mathrm{N}, 51^{\circ} 50^{\prime} \mathrm{E}$ ). The altitude ranges from 8 to $45 \mathrm{~m}$. The climate is typically Mediterranean: about $80 \%$ of relative humidity, no frost; annual rainfall averages $574 \mathrm{~mm}$ (concentrated in November-February) while mean temperature is $16.3{ }^{\circ} \mathrm{C}\left(5.9\right.$ and $28.8{ }^{\circ} \mathrm{C}$ as extreme mean temperatures in January and July, respectively) (data for Montijo air base, $5 \mathrm{~km}$ away). The study was conducted in five land-use units of $1 \mathrm{~km}^{2}$ each, selected according to a gradient of land-use disturbance, from an old-growth corkoak woodland ( $Q$. suber) to a monoculture of an irrigated alfalfa field (Medicago sativa). A unit of eucalyptus plantation (Eucalyptus globulus) was also added to the study in 2002. Table 1 summarizes the land-use interventions and habitat heterogeneity in each unit, based on dominant land-use types in each patch. For more land-use units' details, as well as physical and chemical characterization of the different land-use units, see Sousa et al. (2004). In each land-use unit, a grid of 16 sampling points $(4 \times 4)$ was established; each point $200 \mathrm{~m}$ apart. Within each sampling point carabid beetles were sampled with four unbaited pitfall traps (with ethylene glycol) placed in a quadrat, each pitfall $5 \mathrm{~m}$ apart. Biological material was collected every fortnight in spring (between May and June) and autumn (between September and October).

Ground-beetle activity densities and number of species found at each land-use unit were compared by an ANOVA, followed by a Tukey test. If assumptions of homogeneity of variances and normality (verified previously using Bartlett and Kolmogorov-Smirnov tests, respectively) were not met, data were transformed according to Zar (1996). Groundbeetles activity was also correlated with cork-oak trees' densities along land-use units, in order to check how each species responds to the land-use disturbance gradient.

Table 1

Habitat heterogeneity on each land-use unit (numbers indicate number of sampling points at each habitat type), percentage of woody areas, effective woodland cover (average values of tree + shrub cover) and major interventions

\begin{tabular}{|c|c|c|c|c|c|c|}
\hline & \multirow[t]{2}{*}{ Eucalyptus } & \multirow[t]{2}{*}{ Old-growth } & \multicolumn{3}{|l|}{ Managed mosaics } & \multirow[t]{2}{*}{ Agriculture } \\
\hline & & & Closed & Open & Pastures & \\
\hline \multicolumn{7}{|l|}{ Closed woodland } \\
\hline Eucalyptus & 14 & & & & & \\
\hline Cork-oak & & 8 & 11 & 4 & 4 & \\
\hline Open wood (cork-oak) & & 3 & 5 & 9 & 6 & \\
\hline Shrub area & & 3 & & & 1 & \\
\hline Grassland & 2 & 2 & & & & \\
\hline Pasture & & & & 3 & 5 & \\
\hline Agriculture & & & & & & 16 \\
\hline Woody areas $(\%)$ & 87.5 & 87.5 & 100 & 81.3 & 68.8 & 0 \\
\hline $\begin{array}{l}\text { Effective woodland } \\
\text { cover }(\%)\end{array}$ & 35 & 62.5 & 58.1 & 46.3 & 29.5 & 0 \\
\hline Management level & High & Low & Low & Medium & Medium & High \\
\hline Interventions & $\begin{array}{l}\text { Managed forest } \\
\text { of Eucalyptus } \\
\text { globulus }\end{array}$ & $\begin{array}{l}\text { No understory } \\
\text { management } \\
\text { occurred in the } \\
\text { last } 10-15 \text { years } \\
\text { before sampling }\end{array}$ & $\begin{array}{l}\text { Understory removed } \\
\text { every } 7-8 \text { years } \\
\text { (cleaned recently } \\
\text { before the first } \\
\text { sampling year) }\end{array}$ & $\begin{array}{l}\text { Regular agro-forestry } \\
\text { interventions. } \\
\text { Understory with } 8 \\
\text { years old at the } \\
\text { first sampling year; } \\
\text { occasional grazing }\end{array}$ & $\begin{array}{l}\text { Regular agro-forestry } \\
\text { interventions. } \\
\text { Understory cover } \\
\text { strongly reduced; } \\
\text { high-management } \\
\text { level of extensive } \\
\text { grazing }\end{array}$ & $\begin{array}{l}\text { Homogeneous and } \\
\text { permanently irrigated } \\
\text { alfalfa field } \\
\text { (Medicago sativa) } \\
\text { since } 1988\end{array}$ \\
\hline
\end{tabular}

Eucalyptus: managed monoculture of eucalyptus; old-growth: unmanaged cork-oak woodland; managed mosaics - closed: dominated by closed woodlands, open: dominated by open woodlands, pastures: with more proportion of pasture areas in relation to the other mosaics; agriculture: managed monoculture of alfalfa. 
Correlations were calculated using the Spearman coefficient. All the above statistical calculations were made using the SigmaStat software (SPSS). Finally, the habitat preference profile of each ground-beetle species was checked in the literature, based mainly on Desender and Turin (1989), Turin (2000) and Aguiar and Serrano (unpublished data). This information was needed to analyse the response of different 'habitat preference groups' to the land-use disturbance.

\section{Results}

A total of 4776 individuals from 80 species were sampled in 2001, and 6518 individuals from 77 species in 2002, over all land-use units, comprising a total of 11294 individuals from 101 species in the two years. Among land-use units, the agricultural landscape hosted significantly more individuals and species during the 2 years of study (Fig. 1), with a total of 49 taxa recorded in 2001 and 55 in 2002. The most common species recorded in both years in this unit were Campalita maderae and Pseudophonus rufipes. These species, together with Harpalus distinguendus, showed a high-negative correlation with the increase of cork-oak density, from agriculture patches to closed woodland areas, in both years (Table 2). Nevertheless, Amara aenea was the most dominant species in the agriculture unit, during the second year of sampling (Table 2). In this year, the exotic eucalyptus forest was significantly species poor in relation to the all other units, with a total of only seven taxa recorded. Eucalyptus forest was completely dominated by one single species, i.e., Macrothorax rugosus (Table 2). Mosaic units mainly composed by open areas always recorded a higher carabid abundance and

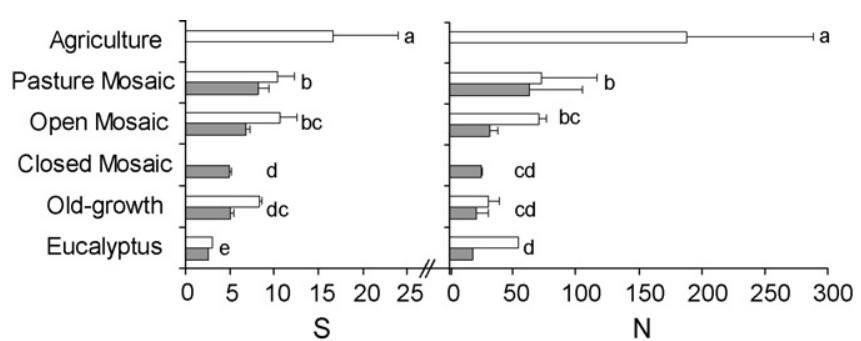

Fig. 1. Ground-beetle abundance ( $N$, number of individuals) and richness ( $S$, number of species) along the land-use disturbance gradient: mean values of the two sampling years. Shaded bars: forested areas; white bars: open areas; "a", "b", "c", "d" and "e" indicate different groups after Tukey test $(p<0.05)$.

richness than the old-growth forest and the mosaic unit mainly composed by closed woodlands (Fig. 1). Open mosaics were mainly dominated by Rhabdotocarabus melancholicus while Steropus globosus was generally more common in closed mosaics. Hadrocarabus lusitanicus and Calathus granatensis were also common across mosaic units (Table 2). These two species were positively correlated with the increase of corkoak density from agriculture patches to closed woodland areas, although only $H$. lusitanicus was significantly correlated in both years (Table 2). Within each mosaic unit, average species richness and abundance were always higher in the open habitats (grasslands, pastures) in relation to forested ones (Fig. 1).

Carabids were grouped according to their "habitat preference profiles' in order to check if the response pattern to disturbance was identical across the different groups. Ubiquitous species were generally dominant along all landuse units, in terms of abundance (43.2\% of carabid

Table 2

Rank of the most common species in the 2 years (2001 and 2002) and their correlation with the cork-oak density (ns, non significant; $p<0.05$ )

\begin{tabular}{|c|c|c|c|c|c|c|c|c|c|c|c|c|c|c|}
\hline & \multirow{2}{*}{ Species rank (code) } & \multicolumn{2}{|c|}{$\begin{array}{l}\text { Spearman's } \\
\text { rho }\end{array}$} & \multirow{2}{*}{$\begin{array}{l}\text { EUC } \\
02 \\
\end{array}$} & \multicolumn{2}{|c|}{ OLD } & \multicolumn{2}{|c|}{ CLO } & \multicolumn{2}{|c|}{ OPE } & \multicolumn{2}{|c|}{ PAS } & \multicolumn{2}{|c|}{ AGR } \\
\hline & & 01 & 02 & & 01 & 02 & 01 & 02 & 01 & 02 & 01 & 02 & 01 & 02 \\
\hline U & Rhabdotocarabus melancholicus & ns & -0.34 & 0.83 & 28.9 & 9.15 & 3.03 & 2.92 & 39.9 & 36.6 & 50.9 & 38 & 0.48 & 1.14 \\
\hline $\mathrm{OH}$ & Campalita maderae & -0.72 & -0.68 & & & $*$ & & & & $*$ & & & 44 & 15.5 \\
\hline $\mathrm{OH}$ & Pseudophonus rufipes & -0.73 & -0.72 & & & $* *$ & & & & & & & 31.1 & 19.4 \\
\hline $\mathrm{U}$ & Amara aenea & ns & -0.69 & & & & & 0.73 & * & & $* *$ & $*$ & 0.48 & 30.6 \\
\hline $\mathrm{U}$ & Steropus globosus & $\mathrm{ns}$ & $\mathrm{ns}$ & 8.33 & 8.3 & 38.7 & 49 & 55.5 & 1.58 & 2.93 & 7.49 & 18.9 & 1.82 & 1.09 \\
\hline W & Hadrocarabuslusitanicus & 0.45 & 0.50 & 2.5 & 12.6 & 21.1 & 20.5 & 20 & 12.3 & 14.3 & 1.6 & 7.43 & 0.59 & 0.39 \\
\hline $\mathrm{U}$ & Macrothorax rugosus & ns & ns & 85.6 & 1.98 & 14.3 & $*$ & 1.22 & 2.3 & 6.04 & 0.58 & 1.18 & $*$ & 0.63 \\
\hline $\mathrm{U}$ & Harpalus rufipalpis & ns & -0.73 & 2.22 & 1.19 & 2.55 & $*$ & 1.46 & 1.15 & 1.47 & 0.7 & 6.42 & & 5.53 \\
\hline W & Calathus granatensis & ns & 0.46 & $*$ & 2.37 & 3.4 & 8.33 & 6.81 & 18.1 & 13.7 & & & * & \\
\hline $\mathrm{OH}$ & Poecilus kugelanni & -0.41 & -0.66 & & $*$ & $*$ & & & & $* *$ & & 0.51 & & 5.22 \\
\hline $\mathrm{OH}$ & Harpalusdistinguendus & -0.64 & -0.66 & & * & & & & & & & $*$ & 6.37 & 2.78 \\
\hline RB & Chlaeniellus nitidilus & ns & $\mathrm{ns}$ & & & & & & 6.03 & & 8.32 & & & \\
\hline $\mathrm{U}$ & Trechus obtusus & -0.55 & -0.37 & * & $* *$ & 0.64 & 3.03 & 1.46 & 5.02 & 5.86 & 0.51 & 1.86 & 2.79 & 0.46 \\
\hline RB & Chlaeniellus olivieri & $\mathrm{ns}$ & $\mathrm{ns}$ & & & & & & 1.29 & & 10.1 & & & \\
\hline RB & Agonum mulleri & $\mathrm{ns}$ & -0.49 & & $*$ & & & & 0.43 & & 5.69 & & 0.32 & \\
\hline
\end{tabular}

Shaded numbers indicate the three more abundant species in each land-use unit per year. *Singletons; **doubletons. EUC: eucalyptus; OLD: old-growth woodland; CLO: closed mosaic; OPE: open mosaic; PAS: pasture mosaic; AGR: agriculture; U: ubiquitous species; OH: open-habitat species; W: woodland species; RB: species from riparian galleries or bogs. 


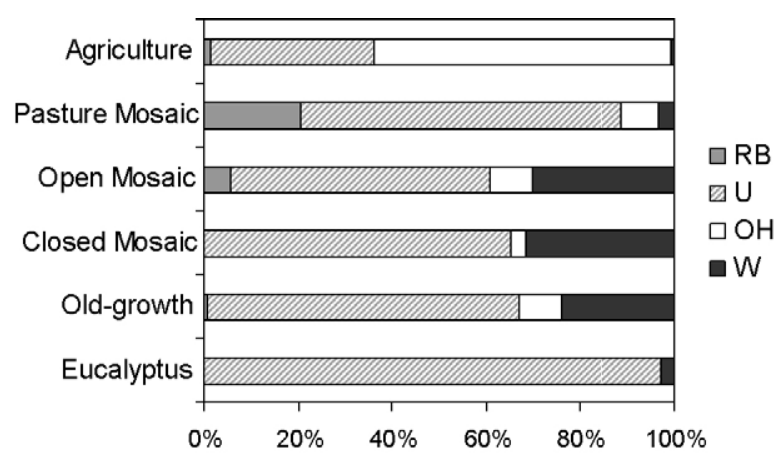

Fig. 2. Ground-beetles' habitat preference groups (percentages of woodland species "W", open-habitat species "OH", ubiquitous species "U" and species from riparian galleries or bogs "RB") from each land-use unit.

abundance in 2001 and $54.1 \%$ in 2002) and species richness (39.7\% of carabid species in 2001 and $33.8 \%$ in 2002). Open-habitat species were the second most abundant and rich group ( $N: 37.7 \%$ in 2001 and $36.7 \%$ in 2002; $S: 29.4 \%$ in 2001 and $32.4 \%$ in 2002) whereas woodland specialists represented lower percentages of abundance and richness ( $N$ : $8.9 \%$ in 2001 and $7.4 \%$ in $2002 ; S: 14.1 \%$ in 2001 and $13 \%$ in 2002). Among land-use units, different groundbeetle composition was found considering their habitat preferences. Ubiquitous ground-beetles were particularly dominant within the eucalyptus unit (Fig. 2). Besides, openhabitat ground-beetles were dominant in the agriculture landscape while a higher relative number of woodland specialists were recorded in mosaic units with more proportion of $Q$. suber woodlands. Considering the main habitat types across all land-use units, woodland specialists were much more abundant and rich in closed and open corkoak woodlands, although pasture patches did not record significantly lower values in relation to the cork-oak areas (Fig. 3).

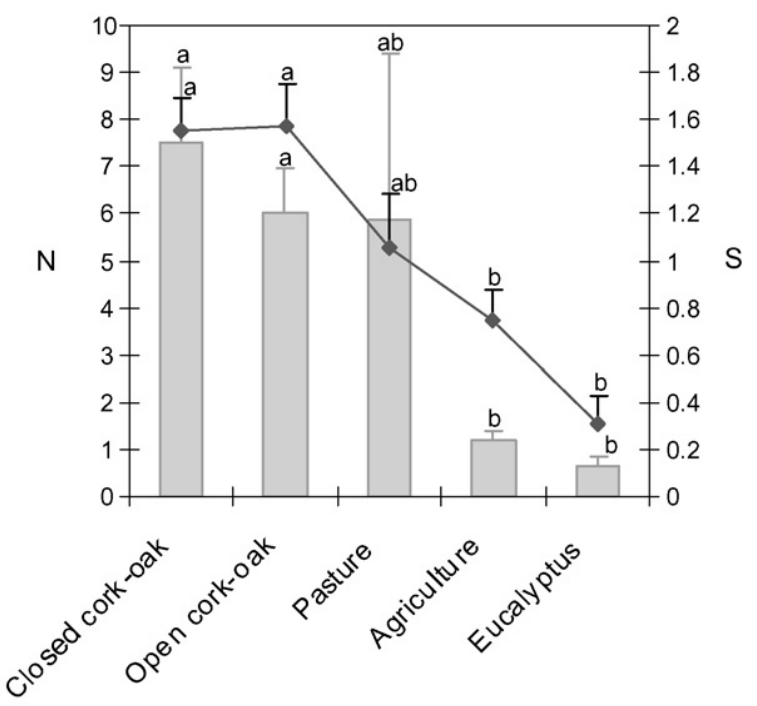

Fig. 3. Woodland ground-beetles' abundance ( $N$, shaded bars) and richness $(S$, dark line): average numbers of the sampling points within each habitat type. "a" and "b" indicate different groups after Tukey test $(p<0.05)$.

\section{Discussion}

Considering IDH, it would be expected that along a gradient of land-use intensification, biodiversity would be higher at intermediate levels of disturbance, i.e., in the most heterogeneous landscape units. Accordingly, the lowest ground-beetle diversity values were recorded in the homogeneous eucalyptus plantation, although this unit did not properly fit within the established woodland-mosaicagriculture gradient. Moreover, the highest species richness and abundance were not observed in the mosaic units, but in the homogeneous and extremely disturbed agriculture landscape. The higher abundance and richness found in units dominated by open areas (particularly pastures), as well as in the open areas within each mosaic unit, also supports the propensity of ground-beetles to be more abundant and species rich in open habitats. This contradiction with the IDH premises has been lately corroborated by several other studies using ground-beetles as indicators (e.g., Brose, 2003; Grandchamp et al., 2005; Vanbergen et al., 2005). Our results can be explained by the predominance of some open-habitat ground-beetles which certainly found in the alfalfa monoculture a large amount of continuous habitat with suitable conditions for their activity. Ubiquitous species were also common across all land-use units. In fact, pitfall surveys are generally dominated by generalists and open-habitat ground-beetles, as their higher mobility and invasive ability allow them to dominate in more exposed habitats (e.g., agricultural areas) where they usually find higher prey availability (Kromp, 1999; Kennedy et al., 2001; Larsen et al., 2003). Taking this into account, the use of ground-beetles from an exclusively taxonomic perspective seems to be an inaccurate tool to test IDH, since biodiversity evaluations will naturally be positively biased towards disturbed/open landscapes. The use of life-traits instead of the traditional "taxonomic approach" might become a more comprehensive tool to assess and monitor biodiversity (e.g., Ribera et al., 2001; Ponge et al., 2006). Concerning ground-beetles, the use of 'habitat preference groups' appears to be an appropriate functional tool to assess different types of land-use management (Döring and Kromp, 2003) bearing in mind that specialist species are more sensitive to habitat disturbance than generalists (Kotze and O'Hara, 2003). According to our results, mosaic units dominated by cork-oak patches presented a higher abundance and species richness of woodland specialists due to the habitats provided by $Q$. suber areas. In contrast with the ubiquitous and open-habitat ground-beetles, the woodland specialists showed a negative response to the disturbance gradient. In terms of the IDH prediction, although the overall ground-beetle abundance and richness increased along the disturbance gradient, the negative response of woodland specialists indicates that the land-use intensification was only beneficial to ubiquitous and openhabitat species. Therefore, the maintenance of habitat heterogeneity comprising $Q$. suber patches, instead of 
homogeneous agriculture areas, is strongly recommended in Mediterranean landscapes.

\section{Acknowledgements}

This study was sponsored by the EU, integrated in the BIOASSESS project (contract no.: EVK4-1999-00280). The authors would like to thank the Administration of Companhia das Lezírias and the Força Aérea PortuguesaCampo de Tiro de Alcochete for allowing the realisation of the field work. We are also grateful to the anonymous referees which contributed to improve this manuscript.

\section{References}

Brose, U., 2003. Regional diversity of temporary wetland carabid beetle communities: a matter of landscape features or cultivation intensity? Agric. Ecosyst. Environ. 98, 163-167.

Desender, K., Turin, H., 1989. Loss of habitat and changes in the composition of the ground and tiger beetle fauna in four West European countries since 1950 (Coleoptera: Carabidae, Cicindelidae). Biol. Conserv. 48, 277-294.

Döring, T.F., Kromp, B., 2003. Which carabid species benefit from organic agriculture? A review of comparative studies in winter cereals from Germany and Switzerland. Agric. Ecosyst. Environ. 98, 153-161.

Grandchamp, A.-C., Bergamini, A., Stofer, S., Niemelä, J., Duelli, P., Scheidegger, C., 2005. The influence of grassland management on ground beetles (Carabidae, Coleoptera) in Swiss montane meadows. Agric. Ecosyst. Environ. 110, 307-317.

Kennedy, P.J., Conrad, K.F., Perry, J.N., Powell, D., Aegerter, J., Todd, A.D., Walters, K.F.A., Powell, W., 2001. Comparison of two field-scale approaches for the study of effects of insecticides on polyphagous predators in cereals. Appl. Soil Ecol. 17, 253-266.

Kotze, D.J., O'Hara, R.B., 2003. Species decline - but why? Explanations of carabid beetle (Coleoptera, Carabidae) declines in Europe. Oecologia 135, 138-148.

Kromp, B., 1999. Carabid beetles in sustainable agriculture: a review on pest control efficacy, cultivation impacts and enhancement. Agric. Ecosyst. Environ. 74, 187-228.

Larsen, K.J., Work, T.T., Purrington, F.F., 2003. Habitat use patterns by ground beetles (Coleoptera: Carabidae) of northeastern Iowa. Pedobiologia 47, 288-299.
Niemelä, J., Baur, B., 1998. Threatened species in a vanishing habitat: plants and invertebrates in calcareous grasslands in the Swiss Jura mountains. Biodivers. Conserv. 7, 1407-1416.

Ponge, J.-F., Dubs, F., Gillet, S., Sousa, J.P., Lavelle, P., 2006. Decreased biodiversity in soil springtail communities: the importance of dispersal and landuse history in heterogeneous landscapes. Soil Biol. Biochem. 38, 1158-1161.

Rainio, J., Niemelä, J., 2003. Ground beetles (Coleoptera: Carabidae) as bioindicators. Biodivers. Conserv. 12, 487-506.

Ribera, I., Dolédec, S., Downie, I.S., Foster, G.N., 2001. Effect of land disturbance and stress on species traits of ground beetle assemblages. Ecology 82, 1112-1129.

Sheil, D., Burslem, D.F.R.P., 2003. Disturbing hypotheses in tropical forests. Trends Ecol. Evol. 18, 18-26.

Sousa, J.P., Gama, M.M., Pinto, C., Keating, A., Calhôa, F., Lemos, M., Castro, C., Luz, T., Leitão, P., Dias, S., 2004. Effects of land-use on Collembola diversity patterns in a Mediterranean landscape. Pedobiologia 48, 609-622.

Sousa, J.P., Bolger, T., Gama, M.M., Lukkaric, T., Ponge, J.F., Simón, C., Traser, G., Vanbergen, A.J., Brennan, A., Dubs, F., Ivitis, E., Keating, A., Stofer, S., Watt, A.D., 2006. Changes in Collembola richness and diversity along a gradient of land-use intensity: a pan European study. Pedobiologia 50, 147-156.

Sroka, K., Finch, O.-D., 2006. Ground beetle diversity in ancient woodland remnants in north-western Germany (Coleoptera, Carabidae). J. Insect Conserv. 10, 335-350.

Taboada, A., Kotze, D.J., Salgado, J.M., Tárrega, R., 2006. The influence of habitat type on the distribution of carabid beetles in traditionally managed "dehesa" ecosystems in NW Spain. Entomol. Fennica 17 (3), 284-293.

Tews, J., Brose, U., Grimm, V., Tielbörger, K., Wichmann, M.C., Schwager, M., Jeltsch, F., 2004. Animal species diversity driven by habitat heterogeneity/diversity: the importance of keystone structures. J. Biogeogr. 31, 79-92.

Turin, H., 2000. De Nederlandse Loopkevers, Verspreiding en Oecologie (Coleoptera: Carabidae). Nederlandse Fauna 3. Nationaal Natuurhistorisch Museum Naturalis, KNNV Uitgeverij \& EIS-Nederland, Leiden.

Vanbergen, A.J., Woodcock, B.A., Watt, A.D., Niemelä, J., 2005. Effect of land-use heterogeneity on carabid communities at the landscape scale. Ecography 28 (1), 3-16.

Verdú, J.R., Crespo, M.B., Galante, E., 2000. Conservation strategy of a nature reserve in Mediterranean ecosystems: the effects of protection from grazing on biodiversity. Biodivers. Conserv. 9, 1707-1721.

Warnaffe, G., du Bus de, Lebrun, P., 2004. Effects of forest management on carabid beetles in Belgium: implications for biodiversity conservation. Biol. Conserv. 118, 219-234.

Zar, J.H., 1996. Biostatistical Analysis. Prentice-Hall International, London. 